\title{
PUBLICATIONS
}

OF THE

\section{UNITED STATES \\ NAVAL OBSERVATORY}

\author{
SEGOND SERIES \\ VOLUME X
}

IN TWO PARTS

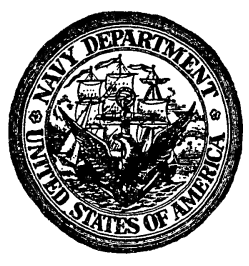

WASHINGTON

GOVERNMENT PRINTING OFFICE

1926 